\title{
Desulfosporosinus lacus sp. nov., a sulfate- reducing bacterium isolated from pristine freshwater lake sediments
}

\author{
S. Ramamoorthy, ${ }^{1}$ H. Sass, ${ }^{2}$ H. Langner, ${ }^{3}$ P. Schumann, ${ }^{4}$ \\ R. M. Kroppenstedt, ${ }^{4}$ S. Spring, ${ }^{4}$ J. Overmann ${ }^{5}$ and R. F. Rosenzweig ${ }^{1}$ \\ ${ }^{1}$ Division of Biological Sciences, Program in Microbial Ecology, University of Montana, Missoula,
}

Correspondence

R. F. Rosenzweig

Frank.Rosenzweig@mso.umt.edu \author{
MT 59812-4824, USA \\ ${ }^{2}$ Institut für Chemie und Biologie des Meeres, Universität Oldenburg, D-26111 Oldenburg, \\ Germany \\ ${ }^{3}$ Department of Geology, University of Montana, Missoula, MT 59812, USA \\ ${ }^{4} \mathrm{DSMZ}$ - Deutsche Sammlung von Mikroorganismen und Zellkulturen GmbH, Mascheroder \\ Weg 1b, D-38124 Braunschweig, Germany \\ ${ }^{5}$ Section Microbiology, Department Biology I, Ludwig-Maximilians-Universität München, \\ Maria-Ward-Str. 1a, D-80638 München, Germany
}

\begin{abstract}
A novel sulfate-reducing bacterium was isolated from pristine sediments of Lake Stechlin, Germany. This strain, STP $12^{\top}$, was found to contain predominantly c-type cytochromes and to reduce sulfate, sulfite and thiosulfate using lactate as an electron donor. Although STP12 ${ }^{\top}$ could not utilize elemental sulfur as an electron acceptor, it could support growth by dissimilatory Fe(III) reduction. In a comparison of $16 \mathrm{~S}$ rRNA gene sequences, STP $12^{\top}$ was $96 \cdot 7 \%$ similar to Desulfosporosinus auripigmenti DSM $13351^{\top}, 96 \cdot 5 \%$ similar to Desulfosporosinus meridiei DSM $13257^{\top}$ and $96.4 \%$ similar to Desulfosporosinus orientis DSM $765^{\top}$. DNA-DNA hybridization experiments revealed that strain STP12 ${ }^{\top}$ shows only $32 \%$ reassociation with the type strain of the type species of the genus, $D$. orientis DSM $765^{\top}$. These data, considered in conjunction with strain-specific differences in heavy metal tolerance, cell-wall chemotaxonomy and riboprint patterns, support recognition of strain STP $12^{\top}\left(=\mathrm{DSM} 15449^{\top}=\mathrm{JCM} 12239^{\top}\right)$ as the type strain of a distinct and novel species within the genus Desulfosporosinus, Desulfosporosinus lacus sp. nov.
\end{abstract}

The genus Desulfosporosinus currently contains three species with validly published names, Desulfosporosinus orientis (Stackebrandt et al., 1997), Desulfosporosinus auripigmenti (Stackebrandt et al., 2003) and Desulfosporosinus meridiei (Robertson et al., 2001). Isolates from locales separated by thousands of kilometres exist for some of these species (e.g. DSM 8344; Vainshtein et al., 1994). Culture- and nonculture-based studies have revealed the existence of Desulfosporosinus-like organisms in environmental settings as diverse as permafrost (Vainshtein et al., 1994), pristine aquifers (Detmers et al., 2004), municipal drinking water (Bade, 2000) and rice plant roots (Scheid et al., 2004).

The GenBank/EMBL/DDBJ accession number for the $16 \mathrm{~S}$ rRNA gene sequence of strain STP12 ${ }^{\top}$ is AJ582757.

A transmission electron micrograph of cells of strain STP12 ${ }^{\top}$, a graph showing lactate oxidation and growth and a summary of the metaltolerance profiles of strain STP $12^{\top}$ and related strains are available as supplementary material in IJSEM Online.
Multiple lines of evidence suggest that members of the genus also commonly inhabit industrially impacted soils and sediments. D. auripigmenti was isolated from an arseniccontaminated watershed, and is one of a limited number of bacteria known to respire arsenate (Newman et al., 1997). Recently, another arsenic-reducing Desulfosporosinus strain was isolated from arsenic-contaminated sediments; this organism has the capacity to metabolize a wide variety of aromatic compounds (Liu et al., 2004). Kusel et al. (2001) reported the isolation of Desulfosporosinus-like organisms from a coal-mining-impacted lake, while Robertson et al. (2000) isolated eight Desulfosporosinus strains from a hydrocarbon-contaminated soil. Two of these were later described as D. meridiei (Robertson et al., 2001) and their activity was linked to toluene mineralization (Robertson et al., 2000; Franzmann et al., 2002). Desulfosporosinus-like strains have repeatedly been seen to dominate subsurface bacterial communities associated with radionuclidecontaminated sediment. This observation is consistent across widely dispersed habitats in the United States that 
include the Midnight Mine, WA (Suzuki et al., 2002), the DOE Field Research Center in Oak Ridge, TN (Shelobolina et al., 2003), and uranium mine tailings in Shiprock, NM (Nevin et al., 2003). Significantly, enrichment of Desulfosporosinus-like microbes has been associated with stimulated removal of solution-phase uranium (Nevin et al., 2003). In such contexts, uranium precipitation may occur secondarily to sulfidogenesis or as a primary result of dissimilatory U(VI) reduction (Suzuki et al., 2002, 2003, 2004).

Herein, we report the isolation and characterization of a novel Desulfosporosinus strain from a pristine environment, sediments of Lake Stechlin, Germany. Strain STP $12^{\mathrm{T}}$ was found by $16 \mathrm{~S}$ rRNA gene sequence comparison to have similarity values of $96 \cdot 4-96 \cdot 7 \%$ relative to other members of the genus; DNA-DNA hybridization experiments revealed only $32 \%$ reassociation with the type strain of the type species, D. orientis DSM $765^{\mathrm{T}}$. We describe genetic and phenotypic attributes of STP $12^{\mathrm{T}}$ investigated in parallel with the three Desulfosporosinus species with validly published names. We contend that ribosomal gene sequence differences and hybridization data, considered along with strain-specific differences in cytochromes, cell-wall chemotaxonomy and riboprint patterns, support recognition of STP $12^{\mathrm{T}}$ as representing a distinct and novel species within the genus Desulfosporosinus.

Strain STP $12^{\mathrm{T}}$ was isolated from the highest positive tubes of a most-probable number (MPN) series inoculated with sediment from Lake Stechlin a pristine, dimictic, oligotrophic freshwater lake located $100 \mathrm{~km}$ north of Berlin (Germany) (Sass et al., 1997). The culture medium used was that described by Widdel \& Pfennig (1977), modified by Widdel (1980). Medium was reduced by addition of $0 \cdot 1 \mathrm{ml}$ freshly prepared sodium dithionate stock solution (3\% w/v). $\mathrm{Na}_{2} \mathrm{SO}_{4}(10 \mathrm{mM})$ and sodium lactate $(10 \mathrm{mM})$ were added separately from sterile anaerobic stocks. Anaerobic techniques were used in all medium preparation and culture manipulations. Physiological attributes of strain STP12 ${ }^{\mathrm{T}}$ were evaluated in parallel with those of other members of the genus Desulfosporosinus. D. meridiei DSM $13257^{\mathrm{T}}$ (Robertson et al., 2001), D. orientis DSM $765^{\mathrm{T}}$ (Campbell \& Postgate, 1965) and D. auripigmenti DSM $13351^{\mathrm{T}}$ (Newman et al., 1997; Stackebrandt et al., 2003) were obtained from the DSMZ. Bacteria were initially cultivated on the appropriate recommended DSMZ medium. Because all strains grew on Widdel \& Pfennig (1977) medium as modified by Widdel (1980), this medium was used for all comparative experiments. Unless otherwise indicated, all physiological experiments were performed in triplicate at $30^{\circ} \mathrm{C}$, lasting until cultures reached stationary phase. Uninoculated media and/or autoclaved cells served as negative controls.

Gram staining was performed using the Fisher Gram stain set protocol (Magee et al., 1975). Spore formation was tested by culturing strains in media containing $10 \mathrm{mM}$ sulfate and $10 \mathrm{mM}$ lactate through late-stationary phase and then assessing presence of spores by phase-contrast light microscopy and transmission electron microscopy (TEM). Cultures deemed positive for spore formation were incubated at $85^{\circ} \mathrm{C}$ for $30 \mathrm{~min}$ and then transferred to fresh medium and monitored for outgrowth.

Samples for negative staining and electron microscopy were pipetted onto a nickel grid coated with $0 \cdot 25 \%$ Formvar solution in ethylene dichloride and stained for 30-60 s with $2 \%$ uranyl acetate. Thereafter, the grid was mounted on a grid holder and viewed using a $1 \mathrm{~K} / 1 \mathrm{~K}$ AMT camera attached to a Hitachi H-7100 transmission electron microscope. Samples for TEM were prepared by fixing cells with Karnovsky's fixative and washing three times with $0 \cdot 1 \mathrm{M}$ sodium cacodylate buffer. Samples were pelleted by centrifugation, embedded in $1 \%$ agarose (with $0.01 \%$ azide), post-fixed with $1 \%$ buffered osmium tetroxide and then dehydrated in a graded ethanol series followed by propylene oxide. Bacterial samples were infiltrated in a polybed 812 resin and polymerized at $60^{\circ} \mathrm{C}$ for 2 days. Sections $(70 \mathrm{~nm})$ were collected on 100-mesh copperrhodium grids, post-stained with $2 \%$ uranyl acetate followed by Reynold's lead citrate (Bozzola \& Russell, 1999 ) and then viewed using a $1 \mathrm{~K} / 1 \mathrm{~K}$ AMT camera attached to a Hitachi H-7100 transmission electron microscope.

To test for the oxidation of lactate coupled with sulfate reduction, mid-exponential phase cells were used to inoculate (5\% inoculum) fresh medium amended with $10 \mathrm{mM}$ lactate and $5 \mathrm{mM}$ sulfate. Negative controls consisted of (i) live cells in fresh medium without lactate, (ii) autoclaved cells added to complete medium (Madigan et al., 1997) and (iii) live cells filtered through a $0 \cdot 2 \mu \mathrm{m}$ sterile filter, with the filtrate added to complete medium. Culture tubes were subsampled periodically to estimate cell number and concentrations of $\mathrm{H}_{2} \mathrm{~S}$, lactate and acetate. Culture densities were estimated spectrophotometrically at $420 \mathrm{~nm}$. Direct cell counting was used to confirm growth on selenate, manganese oxide and $\mathrm{Fe}(\mathrm{III})$. Cells were stained with $10 \mu \mathrm{g} 4^{\prime}$,6-diamidino-2-phenylindole $\mathrm{ml}^{-1}$ (DAPI; Sigma) and then cells were counted by epifluorescence microscopy using a Zeiss Axioskop. Growth yield was defined as bacterial dry mass obtained from a given amount of substrate, as described by Cypionka \& Pfennig (1986).

Oxygen sensitivity was tested by transferring late-exponential phase cells grown on sodium lactate $(10 \mathrm{mM})$ and sodium sulfate $(5 \mathrm{mM})$ into sterile flasks and shaking them under air at $30^{\circ} \mathrm{C}$ for $24 \mathrm{~h}$, whereupon they were reintroduced into anoxic medium containing $10 \mathrm{mM}$ lactate and $5 \mathrm{mM}$ sulfate. Growth was monitored as described below. Production of sulfide was assayed by testing for black FeS precipitate upon addition of $0.05 \%$ $\mathrm{Fe}\left(\mathrm{NH}_{4}\right)_{2}\left(\mathrm{SO}_{4}\right)_{2}$.

Temperature and $\mathrm{pH}$ optima were estimated by culturing cells in basal medium amended with $10 \mathrm{mM}$ sodium lactate and $5 \mathrm{mM}$ sodium sulfate. To determine temperature optima, cells were grown at $\mathrm{pH} 7 \cdot 0$ at $4,10,15,21,28,30$, 32, 37, 42 and $45^{\circ} \mathrm{C}$. To determine $\mathrm{pH}$ optima, the 
bicarbonate buffer was replaced with $20 \mathrm{mM}$ (each) HEPES, PIPES, MES and Tris base and the initial medium $\mathrm{pH}$ was set using $1 \mathrm{M} \mathrm{HCl}$ or $1 \mathrm{M} \mathrm{NaOH}$. Population growth at pH $6 \cdot 0,6 \cdot 5,7 \cdot 0$ and $7 \cdot 5$ was estimated by following the change in optical density; growth rates were calculated using the linear portion of a semi-logarithmic plot of optical density against time.

Desulfosporosinus strains were evaluated for their ability to grow using the electron donors listed in Table 1. Anaerobic stock solutions $(1 \mathrm{M})$ were prepared for each donor and aliquots were added to defined medium to yield the concentrations indicated. Each donor was tested using sulfate $(5 \mathrm{mM})$ as the terminal electron acceptor. Triplicate experiments were initiated by the addition of $10 \%$ midexponential-phase inocula to fresh medium. Change in cell density and sulfide production was monitored as described below. Organisms were considered positive for utilization of an electron donor if 2.5 to 3 doublings occurred after the third passage with simultaneous production of sulfide, as indicated by formation of black precipitate when amended with $0 \cdot 05 \% \mathrm{Fe}\left(\mathrm{NH}_{4}\right)_{2}\left(\mathrm{SO}_{4}\right)_{2}$. Inoculated medium lacking substrate served as a negative control.

Bacteria were also tested for their ability to utilize the terminal electron acceptors indicated in Table 1 using sodium lactate $(10 \mathrm{mM})$ as a carbon source and electron donor. Anaerobic stock solutions (1 M) were prepared for each electron acceptor and aliquots were added to defined medium to yield the indicated concentrations. Experiments were initiated by the addition of $10 \%$ mid-exponentialphase inocula to fresh medium. Change in cell density and

Table 1. Morphological and chemotaxonomic features of STP $12^{\top}$ in relation to described members of the genus Desulfosporosinus

All strains are Gram-negative, display peritrichous flagella and produce oval endospores. Electron acceptors were tested in the presence of $10 \mathrm{mM}$ lactate as the electron donor. Electron donors were tested in the presence of $5 \mathrm{mM}$ sodium sulfate as the electron acceptor. Concentrations (in $\mathrm{mM}$ unless indicated) are given in parentheses. All strains failed to grow in the presence of lactate when provided with either nitrate (5), selenate (10) or Mn(IV) (10). Strains grew equally well in the presence of sulfate when butyrate (5), pyruvate (10), ethanol (10) or yeast extract $\left(1 \mathrm{~g} \mathrm{l}^{-1}\right)$ were provided as electron donors. No strain grew on acetate (10), propionate (5), succinate (1), benzoate (1) or glucose (10) in the presence of sulfate. Use of electron acceptors and donors is scored in terms of $\mathrm{OD}_{420}$ as: - , no growth; + , $<0 \cdot 250 ;++, 0 \cdot 250-0 \cdot 500 ;+++,>0 \cdot 500$. ND, Not determined.

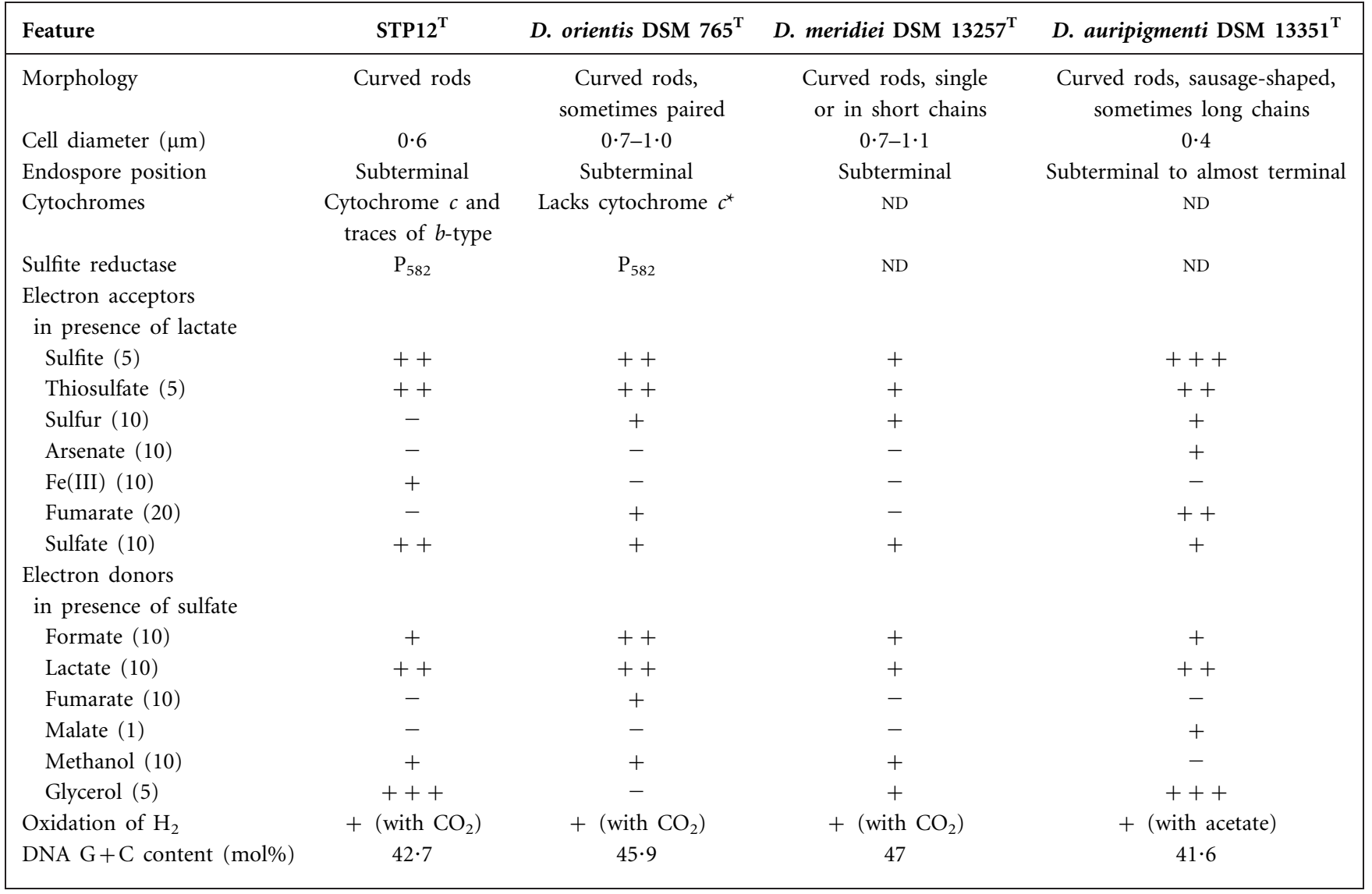

${ }^{*}$ Data from Suzuki et al. (2004). 
sulfide production was monitored as described herein. Organisms were considered positive for utilization of a given electron acceptor if 2.5 to 3 doublings occurred after the third passage. Inoculated medium lacking electron acceptor served as negative control. Reduction of sulfate, sulfite, sulfur and thiosulfate was tested by adding $0.5 \%$ $\mathrm{Fe}\left(\mathrm{NH}_{4}\right)_{2}\left(\mathrm{SO}_{4}\right)_{2}$ to culture tubes. If black FeS precipitate formed, cultures were scored positive for reduction of oxidized sulfur compounds. $\mathrm{MnO}_{2}$ reduction was inferred by a colour change from black $\mathrm{MnO}_{2}$ to white $\mathrm{MnCO}_{3}$, while formation of red elemental selenium precipitate was indicative of $\mathrm{Se}(\mathrm{VI})$ reduction. The change in colour from yellow to white due to the formation of siderite $\left(\mathrm{FeCO}_{3}\right)$ indicated reduction of ferric pyrophosphate $\left[\mathrm{Fe}_{4}\left(\mathrm{P}_{2} \mathrm{O}_{7}\right)_{3}\right]$ to ferrous iron (Coleman et al., 1993).

To test for sulfur disproportionation, strains were grown in modified Pfennig medium to mid-exponential phase and then inoculated into fresh medium containing $10 \mathrm{mM}$ thiosulfate, bisulfite or elemental sulfur. Growth and sulfur disproportionation were inferred by measuring the change in optical density and by testing for sulfide through addition of $0.05 \% \mathrm{Fe}\left(\mathrm{NH}_{4}\right)_{2}\left(\mathrm{SO}_{4}\right)_{2}$ at the end of each experiment. Oxidase and catalase tests were performed as described by Cappuccino \& Sherman (1999).

Metal(loid) tolerance was assayed by inoculating medium containing lactate $(10 \mathrm{mM})$ and $\mathrm{Na}_{2} \mathrm{SO}_{4}(10 \mathrm{mM})$ along with either $\mathrm{Na}_{2} \mathrm{HAsO}_{4} .7 \mathrm{H}_{2} \mathrm{O}, \mathrm{CdSO}_{4}, \mathrm{~K}_{2} \mathrm{CrO}_{4}$ or $\mathrm{ZnSO}_{4}$. The amount of metal added was pre-determined using the geochemical equilibrium-modelling program MINTEQA2 (Allison et al., 1991). Prior to inoculation in metal-amended medium, cells were washed in order to remove all previously produced sulfide. Isolates were considered metal-tolerant if the medium turned black due to formation of $\mathrm{FeS}$ precipitate following addition of $0.05 \% \mathrm{Fe}\left(\mathrm{NH}_{4}\right)_{2}\left(\mathrm{SO}_{4}\right)_{2}$ and cell density increased by more than threefold.

Sulfide (as hydrogen sulfide, $\mathrm{H}_{2} \mathrm{~S}$ ) concentration was estimated by spectrophotometric assay of methylene blue as described by Cline (1969). Reduced arsenic [as arsenite, As (III)] was quantified spectrophotometrically at $865 \mathrm{~nm}$ using the procedure originally described by Johnson \& Pilson (1972), later modified by Niggemyer et al. (2001). Disappearance of lactate and accumulation of acetate in lactate oxidation measurements was determined using ion chromatography. Culture samples were filtered using $0 \cdot 2 \mu \mathrm{m}$ filters before injection onto an ICE-AS6 column connected to a Dionex DX500 chromatography system. Heptafluorobutyric acid $(0.4 \mathrm{mM})$ was the eluent and $5 \mathrm{mM}$ tetrabutyl ammonium hydroxide was used to regenerate the column (Dionex Column manual).

Cells were tested for desulfoviridin using a modification of the method described by Postgate (1959); Desulfovibrio desulfuricans ATCC 27774 was used as a positive control and Escherichia coli $\mathrm{K}-12$ as a negative control. For determination of cytochromes and sulfite reductases, 21 freshly grown culture was gassed with $\mathrm{CO}_{2}$ for 15 min to remove $\mathrm{H}_{2} \mathrm{~S}$ and then centrifuged and the cell pellet was washed with $150 \mathrm{ml}$ $\mathrm{KCl}$. Cell-free extracts were obtained by treatment of cell pellets with a French press and subsequent centrifugation $(12100 \mathrm{~g}, 30 \mathrm{~min})$. Cytochromes and sulfite reductases were analysed by recording redox difference and carbon monoxide difference spectra using a Lambda $2 S$ spectrophotometer (Perkin Elmer). Separation and identification of $b$-type and $c$-type cytochromes were performed as described by Widdel (1980).

Cell-wall preparations were obtained by boiling cells in $20 \%$ $(\mathrm{w} / \mathrm{v})$ aqueous trichloroacetic acid solution for $20 \mathrm{~min}$. Diaminopimelic acid isomers were detected in cell-wall hydrolysates $\left(4 \mathrm{M} \mathrm{HCl}, 100^{\circ} \mathrm{C}, 16 \mathrm{~h}\right.$ ) by TLC on cellulose sheets (Merck) using the solvent system of Rhuland et al. (1955). Isoprenoid quinones were analysed as described previously (Groth et al., 1996). Cellular fatty acid patterns were determined from cells grown to stationary phase in DSMZ medium 641 (http://www.dsmz.de/media). Fatty acid methyl esters were obtained from $40 \mathrm{mg}$ (wet weight) of cells by saponification, methylation and extraction as previously described (Kämpfer \& Kroppenstedt, 1996; Kroppenstedt, 1985; Miller, 1982). Fatty acid methyl ester mixtures were separated by an automated gas chromatographic system (model 5890 Series II and 7673 autosampler; Agilent) controlled by MIS software (Microbial ID). Peaks were automatically integrated and fatty acid names and percentages were determined using the Microbial Identification standard software package (Sasser, 1990).

Universal primers (E. coli positions 8-27F and 1541R) were used to obtain nearly full-length bacterial $16 \mathrm{~S}$ rRNA gene fragments from genomic DNA obtained from pure culture isolates of strain $\mathrm{STP} 12^{\mathrm{T}}$ (as described by Rainey et al., 1996). The resulting PCR product was purified using the Prep-A-gene DNA purification kit (Bio-Rad). Sequencing was done on an Applied Biosystems model 373A automated DNA sequencer using the ABI PRISM dye terminator cycle sequencing kit with AmpliTaq FS (Applied Biosystems) according to the manufacturer's instructions. The almostcomplete 16S rRNA gene sequence of the novel strain was aligned with sequences included in the ARB database or those obtained from the EMBL nucleotide sequence database (http://www.ebi.ac.uk) using tools implemented in the ARB package. The resulting alignment was inspected visually and potential errors were corrected manually. Evolutionary distances were calculated based on the algorithms of Jukes \& Cantor (1969), using neighbour-joining and parsimony methods of tree reconstruction as implemented in the ARB program package. The databases of $16 \mathrm{~S}$ rRNA gene sequences used in this study, as well as the phylogenetic programs, are available at http://www.arb-home.de

Genomic DNA for the determination of DNA base composition and DNA-DNA hybridization studies was isolated using a French pressure cell and purified by chromatography on hydroxyapatite as described by Cashion et al. (1977). The G $+\mathrm{C}$ content was determined by reversedphase HPLC of nucleosides according to Mesbah et al. 
(1989). DNA-DNA hybridization studies were carried out according to the method of De Ley et al. (1970) as modified by Huß et al. (1983), using a Gilford System model 2600 spectrophotometer equipped with a Gilford model 2527-R thermoprogrammer and plotter. Renaturation rates were computed with the TRANSFER.BAS program (Jahnke, 1992). Ribotyping of cultures was performed as described previously using the Qualicon RiboPrinter system (DuPont) with PvuII or EcoRI as restriction enzymes (Bruce, 1996).

\section{Morphology and physiology}

Like other representatives of the genera Desulfosporosinus and Desulfotomaculum, cells of strain $\mathrm{STP} 12^{\mathrm{T}}$ possessed a Gram-negative cell wall. Cells were curved rods which ranged in length from $2 \cdot 3$ to $3 \cdot 8 \mu \mathrm{m}$ and in width from 0.55 to $0.7 \mu \mathrm{m}$ and which were capable of forming conspicuous endospores (see Supplementary Fig. S1 in IJSEM Online). Flagellation was variable; peritrichous flagella were occasionally observed.

Strain STP $12^{\mathrm{T}}$ coupled oxidation of lactate to reduction of sulfate, conserving energy for growth (data not shown), and belonged to physiological group I of the sulfate-reducing bacteria. Such bacteria do not oxidize acetyl CoA to $\mathrm{CO}_{2}$, and therefore excrete acetate. All strains tested utilized lactate and sulfate in a 2:1 ratio. No increase in cell number, depletion of lactate or reduction of sulfate was detected in autoclaved controls. The ratios determined and shown in Supplementary Fig. S2 (available in IJSEM Online) indicate a lactate to sulfate ratio of $2: 1$ only at the beginning of the experiment. Above sulfide concentrations of $4 \mathrm{mM}$, sulfate reduction ceased and lactate seems to be exclusively fermented to acetate. This sulfide sensitivity was already reported for Desulfotomaculum (including Desulfosporosinus) species by Klemps et al. (1985).

Strain STP $12^{\mathrm{T}}$ coupled growth to sulfate respiration over the range $4-32{ }^{\circ} \mathrm{C}$, with $\mu_{\max }$ of $0.08 \mathrm{~h}^{-1}$ at $30{ }^{\circ} \mathrm{C}$. All temperature experiments were conducted at $\mathrm{pH} 7 \cdot 0 . \mathrm{pH}$ optima were determined at $30^{\circ} \mathrm{C}$ as STP $12^{\mathrm{T}}$ attained its $\mu_{\max }$ at that temperature. Sulfidogenic growth of STP $12^{\mathrm{T}}$ was confined to the $\mathrm{pH}$ range $6 \cdot 5-7 \cdot 5$, although in other experiments using different media this strain has been observed to grow above $\mathrm{pH} 8 \cdot 0$ (J. Overmann, unpublished results).

Heat-treated cultures of STP $12^{\mathrm{T}}$ incubated in fresh medium increased in cell density and accumulated sulfide. Bacteria were also capable of growth after $24 \mathrm{~h}$ of exposure to atmospheric oxygen. These observations can be attributed to the ability of the cells to form high-temperature- and oxygen-resistant endospores.

Electron acceptor and donor preferences for all four strains are summarized in Table 1. All Desulfosporosinus strains tested utilized oxidized inorganic sulfur compounds. Yield of strain $\mathrm{STP} 12^{\mathrm{T}}$ was similar on all three oxidized inorganic sulfur compounds (sulfate, sulfite and thiosulfate) $\left(\mathrm{OD}_{420} \approx\right.$ 0.28). However, unlike certain other Desulfosporosinus strains, STP $12^{\mathrm{T}}$ was incapable of using elemental sulfur, fumarate, nitrate or arsenate as electron acceptors. Strain $\mathrm{STP} 12^{\mathrm{T}}$ and D. meridiei DSM $13257^{\mathrm{T}}$ had similar electron donor utilization profiles; $\mathrm{STP} 12^{\mathrm{T}}$ was distinct in that it was able to couple growth to sulfate respiration using glycerol as both electron donor and carbon source. All four Desulfosporosinus strains tested grew on formate, butyrate, pyruvate, lactate, ethanol and yeast extract.

Yield of strain STP $12^{\mathrm{T}}$ was $5.5 \mathrm{~g}$ dry mass per mol lactate when grown at $25^{\circ} \mathrm{C}$. STP $12^{\mathrm{T}}$ also grew autotrophically as a homoacetogen with $\mathrm{H}_{2}$ and $\mathrm{CO}_{2}$. Cell density did not increase and sulfide did not accumulate when cells were cultured on acetate, propionate, fumarate, succinate, malate, glucose or benzoate. STP $12^{\mathrm{T}}$ grew fermentatively on either lactate or pyruvate in the absence of sulfate.

The novel isolate failed to disproportionate sulfur presented in the form of thiosulfate, bisulfite or elemental sulfur. Lack of growth and sulfide production were inferred by the absence of change in $\mathrm{OD}_{420}$ and the absence of black FeS precipitate following addition of $0.05 \% \mathrm{Fe}\left(\mathrm{NH}_{4}\right)_{2}\left(\mathrm{SO}_{4}\right)_{2}$ at the end of each experiment. The novel sulfate reducer STP $12^{\mathrm{T}}$ was both catalase- and oxidase-negative.

Under circumneutral, low $\mathrm{E}_{\mathrm{h}}$ conditions, the production of $\mathrm{H}_{2} \mathrm{~S}$ by sulfate reducers immobilizes solution-phase metal(loid)s as insoluble precipitates. Sulfate reducers have therefore been proposed as agents for accelerated bioremediation of metal-contaminated soils and sediments. With a view towards evaluating their potential in these contexts, we tested the tolerance of STP $12^{\mathrm{T}}$ and its congeners to arsenic, cadmium, zinc and chromium. Results for the four strains are summarized in Supplementary Table S1 available in IJSEM Online. Activity and growth were inferred from the presence of sulfide and change over time in DAPI cell counts. No bacteria tested grew in the presence of $\mathrm{Cr}$, even at the lowest concentration tested $(0.4 \mathrm{mM})$. On the other hand, no strain tested failed to grow in the presence of $2 \mathrm{mM}$ $\mathrm{As}(\mathrm{V})$. Among Desulfosporosinus strains, only strain STP $12^{\mathrm{T}}$ failed to grow in the presence of $10 \mathrm{mM} \mathrm{As}(\mathrm{V})$. Electron acceptor assays, however, clearly demonstrated that only $D$. auripigmenti DSM $13351^{\mathrm{T}}$ had the capacity for dissimilatory $\mathrm{As}(\mathrm{V})$ reduction (data not shown). The highest concentration tested for cadmium $(10 \mu \mathrm{M})$ inhibited growth of all strains except D. auripigmenti DSM $13351^{\mathrm{T}}$. Of all cultures tested, only STP $12^{\mathrm{T}}$ failed to grow in the presence of $50 \mu \mathrm{M}$ zinc, the highest concentration assayed. STP $12^{\mathrm{T}}$ was inhibited even in the presence of $10 \mu \mathrm{M}$ zinc.

\section{Chemotaxonomy}

Cellular fatty acid composition profiles for the novel strain and its three congeners are displayed in Table 2. Fatty acid $16: 1$ cis $9(26 \cdot 3 \%)$ predominated in $\mathrm{STP} 12^{\mathrm{T}}$. The diagnostic amino acid of STP $12^{\mathrm{T}}$ peptidoglycan was LL-diaminopimelic acid. Isoprenoid quinones MK-7 and MK-5 were present in the ratio of $64: 36$ (ratio of peak areas) in strain STP $12^{\mathrm{T}}$. STP $12^{\mathrm{T}}$ demonstrated $\mathrm{P}_{582}$-type sulfite reductases having 
Table 2. Fatty acid composition of novel strain STP $12^{\top}$ and related Desulfosporosinus type strains

Reference strains: 1, D. auripigmenti DSM $13351^{\mathrm{T}}$ (data from Stackebrandt et al., 2003); 2, D. meridiei DSM $13257^{\mathrm{T}}$ (data from this study); 3 , D. orientis DSM $765^{\mathrm{T}}$ (H. Hippe and others, personal communication). dma, Dimethylacetal; ald, aldehyde; cyc, cyclopropane. Values are percentages of total fatty acids; values over $10 \%$ are in bold.

\begin{tabular}{|c|c|c|c|c|c|}
\hline ECL & Fatty acid & STP12 ${ }^{\mathrm{T}}$ & 1 & 2 & 3 \\
\hline $14 \cdot 00$ & $14: 0$ & $3 \cdot 7$ & $2 \cdot 2$ & $3 \cdot 7$ & $4 \cdot 0$ \\
\hline $14 \cdot 63$ & iso- $15: 0$ & $0 \cdot 3$ & & & \\
\hline $14 \cdot 77$ & $15: 2$ & $0 \cdot 4$ & & $2 \cdot 8$ & \\
\hline $14 \cdot 86$ & $15: 1$ cis 9 & & & $1 \cdot 0$ & \\
\hline $14 \cdot 95$ & $16: 0$ ald & $0 \cdot 3$ & $1 \cdot 9$ & $2 \cdot 6$ & $2 \cdot 8$ \\
\hline $15 \cdot 63$ & iso- $16: 0$ & $0 \cdot 5$ & & & \\
\hline $15 \cdot 77$ & $16: 1$ cis 7 & $6 \cdot 0$ & $1 \cdot 5$ & $3 \cdot 5$ & $3 \cdot 0$ \\
\hline $15 \cdot 81$ & $16: 1$ cis 9 & $26 \cdot 3$ & $31 \cdot 6$ & $33 \cdot 4$ & $25 \cdot 5$ \\
\hline $15 \cdot 90$ & $16: 1 c i s 11$ & $2 \cdot 1$ & & $1 \cdot 1$ & $0 \cdot 9$ \\
\hline $16 \cdot 00$ & $16: 0$ & $15 \cdot 1$ & $14 \cdot 2$ & $5 \cdot 8$ & $17 \cdot 4$ \\
\hline $16 \cdot 24$ & $16: 1$ cis $7 \mathrm{dma}$ & & & $1 \cdot 9$ & \\
\hline $16 \cdot 28$ & $16: 1$ cis $9 \mathrm{dma}$ & $1 \cdot 5$ & $1 \cdot 7$ & $5 \cdot 6$ & $1 \cdot 8$ \\
\hline $16 \cdot 47$ & $16: 0 \mathrm{dma}$ & $2 \cdot 5$ & $13 \cdot 4$ & $13 \cdot 5$ & $8 \cdot 7$ \\
\hline $16 \cdot 76$ & Unknown & & & $1 \cdot 3$ & \\
\hline $16 \cdot 77$ & $17: 1$ cis 8 & & $1 \cdot 3$ & $0 \cdot 8$ & \\
\hline $16 \cdot 79$ & $17: 1$ cis 9 & $0 \cdot 6$ & $1 \cdot 1$ & & \\
\hline $16 \cdot 89$ & $17: 0$ сус & & $0 \cdot 6$ & & \\
\hline $17 \cdot 25$ & $18: 1 \mathrm{dma} ?$ & & & $1 \cdot 1$ & \\
\hline $17 \cdot 47$ & $17: 0 \mathrm{dma}$ & & & $1 \cdot 3$ & \\
\hline $17 \cdot 76$ & $18: 1 c i s 9$ & $9 \cdot 3$ & $7 \cdot 5$ & $6 \cdot 1$ & $7 \cdot 5$ \\
\hline $17 \cdot 82$ & $18: 1 c i s 11$ & $16 \cdot 7$ & $2 \cdot 5$ & $3 \cdot 3$ & $5 \cdot 6$ \\
\hline $17 \cdot 92$ & $18: 1 c i s 13$ & $3 \cdot 9$ & $1 \cdot 0$ & $1 \cdot 0$ & $1 \cdot 2$ \\
\hline $18 \cdot 00$ & $18: 0$ & $3 \cdot 6$ & $2 \cdot 8$ & $2 \cdot 2$ & $4 \cdot 3$ \\
\hline $18 \cdot 22$ & $18: 1$ cis $9 \mathrm{dma}$ & $0 \cdot 5$ & $7 \cdot 7$ & $3 \cdot 9$ & $1 \cdot 5$ \\
\hline $18 \cdot 28$ & $18: 1$ cis $11 \mathrm{dma}$ & $1 \cdot 7$ & $4 \cdot 4$ & $4 \cdot 3$ & $1 \cdot 9$ \\
\hline $18 \cdot 47$ & $18: 0 \mathrm{dma}$ & & $2 \cdot 0$ & & $1 \cdot 1$ \\
\hline $19 \cdot 36$ & 19:0 сус dma & $0 \cdot 6$ & & & \\
\hline $19 \cdot 77$ & $20: 1$ cis 11 & $1 \cdot 7$ & & & \\
\hline $19 \cdot 83$ & $20: 1$ cis 13 & $0 \cdot 7$ & & & \\
\hline
\end{tabular}

absorption maxima at $592 \mathrm{~nm}$, and c-type cytochromes $\left(\lambda_{\max } 553 \mathrm{~nm}\right)$, although traces of $b$-type cytochromes were also observed in cell-free extracts.

\section{Phylogeny and comparative genomics}

Ribotype patterns were derived from restriction endonuclease digestion of chromosomal DNA followed by hybridization to probes for sequences that encode the 5S16S-23S rRNA operon (Barney et al., 2001). These patterns have been shown to discriminate among closely related bacterial strains (Scott et al., 2003). The ribotype pattern of strain STP $12^{\mathrm{T}}$ was distinct from the type strains of the other described Desulfosporosinus species (data not shown).

The DNA G + C content of strain STP $12^{\mathrm{T}}$ was $42 \cdot 7 \mathrm{~mol} \%$.

Fig. 1 depicts phylogenetic relationships for the novel strain. Sequence similarity values based on the comparison of almost-complete $16 \mathrm{~S}$ rRNA gene sequences indicate that strain STP $12^{\mathrm{T}}$ is $96.5 \%$ similar to D. meridiei DSM $13257^{\mathrm{T}}$, $96 \cdot 4 \%$ similar to D. orientis DSM $765^{\mathrm{T}}$ and $96 \cdot 7 \%$ similar to D. auripigmenti DSM $13351^{\mathrm{T}}$.

Current thinking holds to the view that, when DNA-DNA hybridization values between two strains are less than $70 \%$, the strains warrant recognition as members of separate species (Stackebrandt \& Goebel, 1994). DNA-DNA hybridization experiments reveal that strain STP $12^{\mathrm{T}}$ shows only $32 \%$ reassociation with $D$. orientis DSM $765^{\mathrm{T}}$. STP $12^{\mathrm{T}}$ is also distinguished phenotypically from other members of the genus by its unique fatty acid profile, its inability to use $S^{0}$ as an electron acceptor and its ability to reduce iron. Altogether, these data support recognition of STP $12^{\mathrm{T}}$ as representing a novel species.

\section{Description of Desulfosporosinus lacus sp. nov.}

Desulfosporosinus lacus (la'cus. L. n. lacus -us a lake; L. gen. n. lacus of a lake).

Cells are rod-shaped, stain Gram-negative and have peritrichous flagella. Individual cell dimensions vary from 0.55 to $0.7 \mu \mathrm{m}$ in width and 2.3 to $3.8 \mu \mathrm{m}$ in length. They produce heat-resistant endospores that are oval and subterminal and which sometimes cause the cells to swell. Utilizes sulfate, sulfite, thiosulfate and $\mathrm{Fe}(\mathrm{III})$ as terminal electron acceptors in the presence of lactate. Arsenate, fumarate, nitrate, sulfur, selenate and $\mathrm{Mn}(\mathrm{IV})$ are not used as electron acceptors. In the presence of sulfate, $\mathrm{H}_{2} / \mathrm{CO}_{2}$,

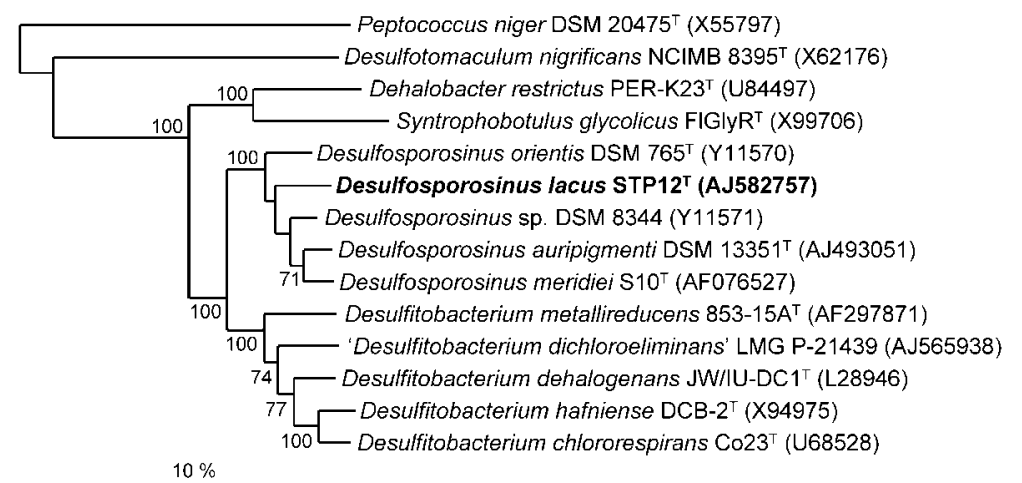

Fig. 1. Unrooted phylogenetic tree based on an alignment of almost-complete $16 \mathrm{~S}$ rRNA gene sequences showing the affiliation of the novel strain STP12 $2^{\top}$ to the genus Desulfosporosinus. The neighbour-joining method of Saitou \& Nei (1987) was used to reconstruct the matrix and the algorithm described by Jukes \& Cantor (1969) was used to calculate phylogenetic distance values. Only bootstrap values above $70 \%$ (1000 resamplings for each node) are shown at the respective branching points. Bar, $10 \%$ estimated sequence divergence. 
$\mathrm{H}_{2} / \mathrm{CO}_{2}$ plus acetate, formate, butyrate, pyruvate, lactate, ethanol, methanol, yeast extract and glycerol are utilized as electron donors and carbon sources. Cannot use acetate, propionate, benzoate, fumarate, succinate, malate or glucose as electron donors or carbon sources. Cells are capable of fermentative growth using pyruvate and lactate as energy sources in the absence of any electron acceptor. The temperature and $\mathrm{pH}$ ranges for growth are $4-32{ }^{\circ} \mathrm{C}$ and $\mathrm{pH} 6 \cdot 5-7 \cdot 5$. Possesses a $\mathrm{P}_{582}$-type sulfite reductase and $c$ type cytochromes with traces of $b$-type cytochromes. The diagnostic diamino acid of the peptidoglycan is LLdiaminopimelic acid. The predominant whole-cell fatty acids are 16:1cis $9,16: 0,18: 1$ cis $11,16: 1$ cis7. The major isoprenoid quinones are MK-7 and MK-5. The DNA G+C content of the type strain is $42 \cdot 7 \mathrm{~mol} \%$.

The type strain, STP $12^{\mathrm{T}}\left(=\right.$ DSM $\left.15449^{\mathrm{T}}=\mathrm{JCM} 12239^{\mathrm{T}}\right)$, was isolated from sediment of Lake Stechlin (northern Germany).

\section{Acknowledgements}

The authors gratefully acknowledge grant support from the US Geological Survey (99-HQGR-0218), the National Science Foundation (EPS-00-91995) and the US Department of Energy (DE-FG0200ER63036) to R.F.R. The technical assistance of I. Kramer (DSMZ) is acknowledged. We thank Jean Euzéby for his assistance in correctly naming the species. The manuscript was significantly improved by the critical commentary of David Nicholas, Johnnie Moore, Terry Paulish and two anonymous reviewers.

\section{References}

Allison, J. D., Brown, D. S. \& Novo-Gradac, K. J. (1991). MINTEQA2/PRODEFA2, a Geochemical Assessment Model for Environmental Systems. EPA/600/3-91/021. Cincinnati, OH: US Environmental Protection Agency.

Bade, K. (2000). Survival of sulfate-reducing bacteria in oxic, oligotrophic environments related to drinking water. Doctoral dissertation, Technical University of Berlin, Berlin, Germany. http://edocs.tu-berlin.de/diss/2000/bade_karen.htm

Barney, M., Volgyi, A., Navarro, A. \& Ryder, D. (2001). Riboprinting and 16S rRNA gene sequencing for identification of brewery Pediococcus isolates. Appl Environ Microbiol 67, 553-560.

Bozzola, J. J. \& Russell, L. D. (1999). Electron Microscopy - Principles and Techniques for Biologists, 2nd edn. Boston: Jones and Bartlett.

Bruce, J. L. (1996). Automated system rapidly identifies and characterizes microorganisms in food. Food Technol 50, 77-81.

Campbell, L. L. \& Postgate, J. R. (1965). Classification of the sporeforming sulfate-reducing bacteria. Bacteriol Rev 29, 359-363.

Cappuccino, J. G. \& Sherman, N. (1999). Microbiology - $a$ Laboratory Manual, 5th edn. Menlo Park, CA: Benjamin/Cummings.

Cashion, P., Holder-Franklin, M. A., McCully, J. \& Franklin, M. (1977). A rapid method for the base ratio determination of bacterial DNA. Anal Biochem 81, 461-466.

Cline, J. D. (1969). Spectrophotometric determination of hydrogen sulfide in natural waters. Limnol Oceanogr 14, 454-458.

Coleman, M. L., Hedrick, D. B., Lovley, D. R., White, D. C. \& Pye, K. (1993). Reduction of $\mathrm{Fe}(\mathrm{III})$ in sediments by sulphate-reducing bacteria. Nature 361, 436-438.
Cypionka, H. \& Pfennig, N. (1986). Growth yields of Desulfotomaculum orientis with hydrogen in chemostat culture. Arch Microbiol 143, 366-369.

De Ley, J., Cattoir, H. \& Reynaerts, A. (1970). The quantitative measurement of DNA hybridization from renaturation rates. Eur J Biochem 12, 133-142.

Detmers, J., Strauss, H., Schulte, U., Bergmann, A., Knittel, K. \& Kuever, J. (2004). FISH shows that Desulfotomaculum spp. are the dominating sulfate-reducing bacteria in a pristine aquifer. Microb Ecol 47, 236-242.

Franzmann, P. D., Robertson, W. J., Zappia, L. R. \& Davis, G. B. (2002). The role of microbial populations in the containment of aromatic hydrocarbons in the subsurface. Biodegradation 13, 65-78.

Groth, I., Schumann, P., Weiss, N., Martin, K. \& Rainey, F. A. (1996). Agrococcus jenensis gen. nov., sp. nov., a new genus of actinomycetes with diaminobutyric acid in the cell wall. Int J Syst Bacteriol 46, 234-239.

Huß, V. A. R., Festl, H. \& Schleifer, K. H. (1983). Studies on the spectrophotometric determination of DNA hybridization from renaturation rates. Syst Appl Microbiol 4, 184-192.

Jahnke, K. D. (1992). Basic computer program for evaluation of spectroscopic DNA renaturation data from Gilford system 2600 spectrophotometer on a PC/XT/AT type personal computer. J Microbiol Methods 15, 61-73.

Johnson, D. L. \& Pilson, M. E. (1972). Spectrophotometric determination of arsenite, arsenate, and phosphate in natural waters. Anal Chim Acta 58, 289-299.

Jukes, T. H. \& Cantor, C. R. (1969). Evolution of protein molecules. In Mammalian Protein Metabolism, pp. 21-132. Edited by H. N. Munro. New York: Academic Press.

Kämpfer, P. \& Kroppenstedt, R. M. (1996). Numerical analysis of fatty acid patterns of coryneform bacteria and related taxa. Can J Microbiol 42, 989-1005.

Klemps, R., Cypionka, H., Widdel, F. \& Pfennig, N. (1985). Growth with hydrogen, and further physiological characteristics of Desulfotomaculum species. Arch Microbiol 143, 203-208.

Kroppenstedt, R. M. (1985). Fatty acid and menaquinone analysis of actinomycetes and related organisms. In Chemical Methods in Bacterial Systematics, SAB Technical Series, no. 20, pp. 173-179. Edited by M. Goodfellow \& D. E. Minnikin. London: Academic Press Kusel, K., Roth, U., Trinkwalter, T. \& Peiffer, S. (2001). Effect of pH on the anaerobic microbial cycling of sulfur in mining-impacted freshwater lake sediments. Environ Exp Bot 46, 213-223.

Liu, A., Garcia-Dominguez, E., Rhine, E. D. \& Young, L. Y. (2004). A novel arsenate respiring isolate that can utilize aromatic substrates. FEMS Microbiol Ecol 48, 323-332.

Madigan, M. T., Martinko, J. M. \& Parker, J. (1997). Brock: Biology of Microorganisms, 8th edn. Upper Saddle River, NJ: Prentice Hall.

Magee, C. M., Rodeheaver, G., Edgerton, M. T. \& Edlich, R. F. (1975). A more reliable gram staining technic for diagnosis of surgical infections. Am J Surg 130, 341-346.

Mesbah, M., Premachandran, U. \& Whitman, W. B. (1989). Precise measurement of the $\mathrm{G}+\mathrm{C}$ content of deoxyribonucleic acid by high-performance liquid chromatography. Int J Syst Bacteriol 39, 159-167.

Miller, L. T. (1982). Single derivatization method for routine analysis of bacterial whole-cell fatty acid methyl esters, including hydroxy acids. J Clin Microbiol 16, 584-586.

Nevin, K. P., Finneran, K. T. \& Lovley, D. R. (2003). Microorganisms associated with uranium bioremediation in a high-salinity subsurface sediment. Appl Environ Microbiol 69, 3672-3675. 
Newman, D. K., Kennedy, E. K., Coates, J. D., Ahmann, D., Ellis, D. J., Lovley, D. R. \& Morel, F. M. (1997). Dissimilatory arsenate and sulfate reduction in Desulfotomaculum auripigmentum sp. nov. Arch Microbiol 168, 380-388.

Niggemyer, A., Spring, S., Stackebrandt, E. \& Rosenzweig, R. F. (2001). Isolation and characterization of a novel As(V)-reducing bacterium, implications for arsenic mobilization and the genus Desulfitobacterium. Appl Environ Microbiol 67, 5568-5580.

Postgate, J. R. (1959). A diagnostic reaction of Desulphovibrio desulphuricans. Nature 183, 481-482.

Rainey, F. A., Ward-Rainey, N., Kroppenstedt, R. M. \& Stackebrandt, E. (1996). The genus Nocardiopsis represents a phylogenetically coherent taxon and a distinct actinomycete lineage: proposal of Nocardiopsaceae fam. nov. Int J Syst Bacteriol 46, 1088-1092.

Rhuland, L. E., Work, E., Denman, R. F. \& Hoare, D. S. (1955). The behavior of the isomers of $\alpha, \varepsilon$-diaminopimelic acid on paper chromatograms. J Am Chem Soc 77, 4844-4846.

Robertson, W. J., Franzmann, P. D. \& Mee, B. J. (2000). Sporeforming, Desulfosporosinus-like sulphate-reducing bacterium from a shallow aquifer contaminated with gasoline. J Appl Microbiol 88, 248-259.

Robertson, W. J., Bowman, J. P., Franzmann, P. D. \& Mee, B. J. (2001). Desulfosporosinus meridiei sp. nov., a spore-forming sulfatereducing bacterium isolated from gasolene-contaminated groundwater. Int J Syst Evol Microbiol 51, 133-140.

Saitou, N. \& Nei, M. (1987). The neighbor-joining method: a new method for reconstructing phylogenetic trees. Mol Biol Evol 4, 406-425.

Sass, H., Cypionka, H. \& Babenzien, H.-D. (1997). Vertical distribution of sulfate-reducing bacteria at the oxic-anoxic interface in sediments of the oligotrophic Lake Stechlin. FEMS Microbiol Ecol 22, 245-255.

Sasser, M. (1990). Identification of bacteria by gas chromatography of cellular fatty acids. USFCC Newsl 20, 1-6.

Scheid, D., Stubner, S. \& Conrad, R. (2004). Identification of rice root associated nitrate, sulfate and ferric iron reducing bacteria during root decomposition. FEMS Microbiol Ecol 50, 101-110.
Scott, T. M., Parveen, S., Portier, K. M., Rose, J. B., Tamplin, M. L., Farrah, S. R., Koo, A. \& Lukasik, J. (2003). Geographical variation in ribotype profiles of Escherichia coli isolates from humans, swine, poultry, beef, and dairy cattle in Florida. Appl Environ Microbiol 69, 1089-1092.

Shelobolina, E. S., O’Neill, K., Finneran, K. T., Hayes, L. A. \& Lovley, D. R. (2003). Potential for in situ bioremediation of a low-pH, highnitrate uranium-contaminated groundwater. Soil Sediment Contam 12, 865-884.

Stackebrandt, E., Sproer, C., Rainey, F. A., Burghardt, J., Pauker, O. \& Hippe, H. (1997). Phylogenetic analysis of the genus Desulfotomaculum: evidence for the misclassification of Desulfotomaculum guttoideum and description of Desulfotomaculum orientis as Desulfosporosinus orientis gen. nov., comb. nov. Int J Syst Bacteriol 47, 1134-1139.

Stackebrandt, E., Schumann, P., Schüler, E. \& Hippe, H. (2003). Reclassification of Desulfotomaculum auripigmentum as Desulfosporosinus auripigmenti corrig., comb. nov. Int $J$ Syst Evol Microbiol 53, 1439-1443.

Suzuki, Y., Kelly, S. D., Kemner, K. M. \& Banfield, J. F. (2002). Nanometre-sized products of uranium bioreduction. Nature 419, 134.

Suzuki, Y., Kelly, S. D., Kemner, K. M. \& Banfield, J. F. (2003). Microbial populations stimulated for hexavalent uranium reduction in uranium mine sediment. Appl Environ Microbiol 69, 1337-1346.

Suzuki, Y., Kelly, S. D., Kemner, K. M. \& Banfield, J. F. (2004). Enzymatic U(VI) reduction by Desulfosporosinus species. Radiochim Acta 92, 11-16.

Vainshtein, M., Gogotova, G. \& Hippe, H. (1994). A sulphatereducing bacterium from the permafrost. In Viable Microorganisms in Permafrost, pp. 68-74. Edited by D. Gilichinsky. Pushchino: Russian Academy of Science Pushchino Research Centre.

Widdel, F. (1980). Anaerober Abbau von Fettsauren und Benzoesaure durch neu isolierte Arten Sulfat-reduzierender Bakterian. Doctoral thesis, University of Gottingen, Gottingen, West Germany.

Widdel, F. \& Pfennig, N. (1977). A new anaerobic, sporing, acetateoxidizing, sulfate-reducing bacterium, Desulfotomaculum (emend.) acetoxidans. Arch Microbiol 112, 119-122. 